\title{
The jökulhlaup from Katla in 1918
}

\author{
Haukur Tómasson \\ Orkustofnun .National Energy Authority, Grensísvegi 9, IS-108 Reykjavik, Iceland
}

\begin{abstract}
The greatest event in the 20th-century glaciological history of Iceland has been the glacier burst of Katla on Saturday 12 October 1918. Several cubic kilometres of water and ice were transported by the burst, and over $0.5 \mathrm{~km}^{3}$ of magma surfaced from the Katla caldera. The volcanic material was transported by air and water, and part of it probably formed pillow lava at the eruption site. The volcanic material transported by water was deposited mostly on the Mýrdalssandur plain and at the coast, but part of it was probably carried out to greater depths by gravity currents as the water entered the sea. The peak flow rate during the jökulhlaup was probably over $3 \times 10^{5} \mathrm{~m}^{3} \mathrm{~s}^{-1}$ of water, with a further $25 \mathrm{Kt} \mathrm{s}^{-1}$ of ice and a similar amount of sediment.
\end{abstract}

\section{INTRODUCTION}

The aim of this paper is to provide an estimate of the maximum discharge of water during the Katlajökulhlaup in 1918, based on measured flood-marks and indications of the flood level. The total volume of flood material is calculated from the measured and estimated volume of eruption material. Eyewitness accounts of the flood are analyzed. A detailed description of the eruption of the volcano Katla and the associated glacier burst ("jökulhlaup" in Icelandic) of Katla in 1918 is found in two booklets which were published in 1919. One was compiled by G. Jóhannsson, a teacher in the settlement at Vík (Jóhannsson, 1919); the other was written by G. Sveinsson, the sheriff at Vík (Sveinsson, 1919). There are some differences between these two accounts even though both use excellent informants from both sides of the Mýrdalssandur flood plain. Jóhannsson himself took part in expeditions to investigate the signs left by the flood, and he had as informant K. L. Markússon at Hjörleifshöfdi. The latter had the best conditions to watch the flood as he lived on an island in the middle of the flood path, and also had the enthusiasm and ability to give a good eyewitness account.

\section{PROPERTIES OF THE FLOW}

The content of the outburst has been much discussed. The burst has generally been considered a water flood, but Jónsson (1982) considers it to have been a debris flow containing about 80\% solid material. Maizels (1991, 1992,1993 agrees with Jónsson, and proposes that 50 $80 \%$ of its volume was solid material. Björnsson (1993) has discussed this point and defined a water flood as liquid containing less than $20 \%$ by volume of solid material, supersaturated mud flow as containing 20-47\% and debris flow as containing over $47 \%$ by total volume of solids. Björnsson considers the burst from Katla in 1918 to have been a borderline case between a water flood and a supersaturated mud flow. Karlsson (1984) claims that the description by Markússon from Hjörleifshöfoi proves that the burst was a water flood. The present author agrees with Karlsson on this point.

The flood liquid was produced by melting of glacier ice by the injection of molten lava. It can be assumed that the flood liquid would have consisted of both meltwater and cooled and solidified lava which had exploded to form ash. Lava can, on cooling, melt approximately 3.5 times its weight of water (Björnsson, 1993). The flood liquid also contained some rock fragments, which were picked up by erosion under Höfdabrekkujökull or released from the ice on the way, as well as xenoliths from the magma. According to measurements by the Technological Institute of Iceland (Einarsson, 1979) these rock fragments form about $10 \%$ by volume of the sandur deposits but about $25 \%$ by weight. The density of the flood liquid was therefore $1170 \mathrm{~kg} \mathrm{~m}^{-3}$. The water-borne phase of the eruption should, according to Björnsson's definitions, be considered a water flood, rating well below the limit for a supersaturated flow.

In assessing the maximum solid content it is assumed that all the material arising from the eruption was carried away by the glacier burst. This was not in fact the case. It is likely that, initially, part of the erupted material formed pillow lava which provided heat to melt the ice without adding any volcanic detritus to the melted product. In addition, a significant component of the eruptive outburst became airborne as ash, falling on the glacier and surrounding area. This ash probably left a significant part of its thermal energy to melt the ice in the crater. The volume of solids in the water in this eruptive phase was probably considerably less than in the early stages of the eruption. 


\section{DESCRIPTION OF THE START OF THE ERUPTION AND THE FLOOD}

The course of events as described by Jóhannsson (1919) and Sveinsson (1919) and their sources is as follows. A large earthquake occurred at $1300 \mathrm{~h}$ followed by $30 \mathrm{~min}$ of continuous tremors. In the eastern part of Mýrdalssandur the sound of rushing water and crashing could be heard soon after the earthquake or series of tremors. The timing of this event is known, because at Medalland, about $30-35 \mathrm{~km}$ east of the eruption site, the roar is said to have begun soon after a weak earthquake was felt. This roaring and crashing signalled the beginning of the burst which had broken out high up in the glacier. Figure 1 shows the course of the jökulhlaup and the locations of the glaciers, mountains and river courses mentioned below.

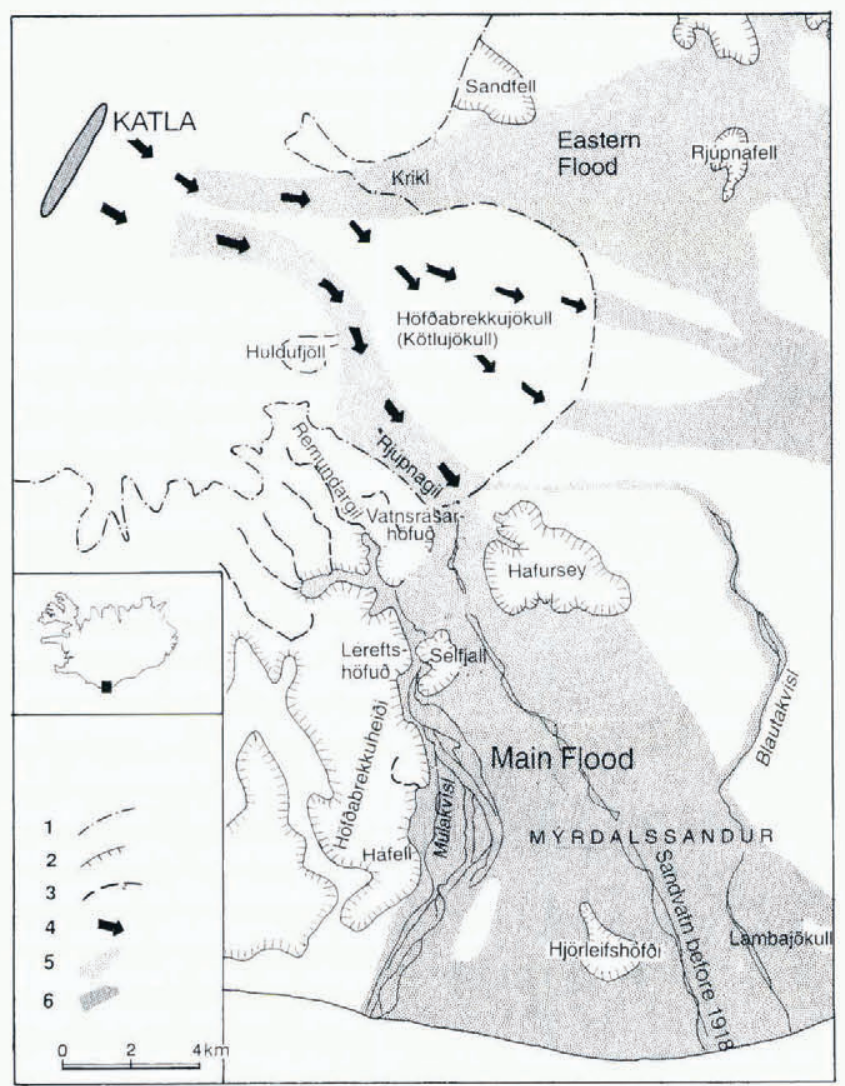

Fig. 1. An overview of the flood path with the location of Katla and supposed flow paths on and under Höfaabrekkujökull. 1, The glacier edge at 1918; 2, steep cliffs; 3, gorges and canyons; 4, supposed flow channels under the glacier; 5, flow on the glacier and the sand plain; 6, the Katla volcano.

The eruption commenced at $1500 \mathrm{~h}$. Observations from Vík and Hjörleifshöfoi agree on this. Jóhannson says: "At the same time as the eruption cloud was noticed here, or a little later, the glacier flood could be seen racing along the course of Múlakvísl all the way to the sea". At Hjörleifshöfi, shortly after he saw the eruption cloud, Mr Markússon heard water streaming to the east of Höfдi (Hjörleifshöfdi). He hastened up the mountain and describes what he saw: "A terrible flood had then broken a way between Hafursey and Selfjall and pushed forward with incredible speed over all the old course of Sandvatn. Its width was from Hjörleifshöfði in the west, all the way east to Blautakvísl. No dry patch could be seen standing above all this area. The water carried with it many icebergs; some fairly large and others smaller'. This description gives some idea of the speed of the flood. Markússon heard the flood to the east of Höfdi, presumably when he was at home. He walked about $1 \mathrm{~km}$ and climbed about $80-100 \mathrm{~m}$ up the mountain, which must have taken him at least $10 \mathrm{~min}$. The burst had not reached the sea when he saw it but appeared well on its way. If when he heard the burst it had reached as far south as Hafursey, then the speed of the burst at this time was about $10 \mathrm{~m} \mathrm{~s}^{-1}$.

Jónsson (1980) refers to an account of an article which Markússon wrote that recorded in detail what he saw on that fateful day. This article by Markússon is lost, but E. H. Einarsson remembered it for Jónsson. It said: "The speed of the burst was so great that a fit man could not have avoided it even if he only needed to go a short distance". This presumably means that the speed of the burst was about that of a sprinting man, or about $10 \mathrm{~m} \mathrm{~s}^{-1}$, the same speed as suggested above.

The leading edge of the burst rushed from the glacier margin to the sea within $45 \mathrm{~min}$. It was fastest where it followed the course of the river Sandvatn which at that time drained the western part of Höfðabrekkujökull. The flood in Múlakvísl reached the sea at the same time, although its flood path was $2-3 \mathrm{~km}$ shorter. The flood seemed steady for up to $2 \mathrm{~h}$. The flood discharge then suddenly increased as described by Markússon as follows: "At 5 p.m. the flood increased very much. Between Hafursey and Selfjall such a big heap of ice appeared that it was like whole hillocks covered in snow flowed forward. This huge amount of ice rushed forward east by the island [Hafursey] and west past Selfjall and then over the whole sand plain". From Vík this was described in the following way by Jóhannsson: "There is no halt in this torrential jökulhlaup at Múlakvísl until 5:30 p.m. But as soon as it seems to be easing, an even greater jökulhlaup seems to rush forward to the west of Hjörleifshöfði". It is noteworthy that the increase in the flood was seen $30 \mathrm{~min}$ later from Vík than at Hjörleifshöfdi. The reason for this is that Markússon saw the increase as it occurred by Hafursey, whereas the inhabitants of Vík did not see it until it was level with Hjörleifshöfði, $10 \mathrm{~km}$ downstream. The heap of ice, according to Jóhannsson and Markússon, travelled this distance in $30 \mathrm{~min}$, giving us a flood-wave velocity of $6 \mathrm{~m}$ $\mathrm{s}^{-1}$. Taking into account that the timings of both observations may have been rounded to the nearest half-hour, this means that a flow velocity similar to that of the initial edge of the flood, about $10 \mathrm{~m} \mathrm{~s}^{-1}$, can be inferred.

The flood continued for about $2 \mathrm{~h}$ after the change occurred, or until darkness which was at $1900 \mathrm{~h}$. At dawn the next day, which was about $12 \mathrm{~h}$ later, the flood was said to be over and the sandur plain was dry. It is likely that the flood receded soon after darkness. The main flood therefore lasted for about $5-6 \mathrm{~h}$ before it began to decrease significantly. 


\section{SOLID CONTENT AND AMOUNT OF VOLCANIC MATERIAL}

The bulk of the volcanic material was most likely transported by the flood water. The remainder became airborne or piled up at the eruption site, forming palagonite tuff and pillow lava. The changes that occurred on Mýrdalssandur give the best indication of the volume of material transported by the flood. These changes can be determined from maps of the area made by the Danish Ordnance Survey in 1904 and by an equivalent institution of the U.S. Army, Army Map Service (AMS), in 1946. The AMS used the Danish survey for ground control in the photogrammetry. The maps are therefore directly comparable. The contours of these maps are similar outside of the flood path of Sandvatn and Múlakvísl, but the contours of the more recent map are offset southwards in the flooded area. The reason for this difference is that the ash transported by the flood was deposited on Mýrdalssandur and built up Kötlutangi. Figure 2 shows the contours of both these maps, over the flood path. The volume of volcanic material above sea level, as calculated from the difference between the contours of the two maps, is $950 \times 10^{6} \mathrm{~m}^{3}$, or a little less than $1 \mathrm{~km}^{3}$.

The amount of volcanic material below sea level at Kötlutangi is not directly measurable. Sveinsson says that "Kötlutangi now reaches out to forty fathoms" (73 m; "now" refers in this context to 16 October 1918). There is

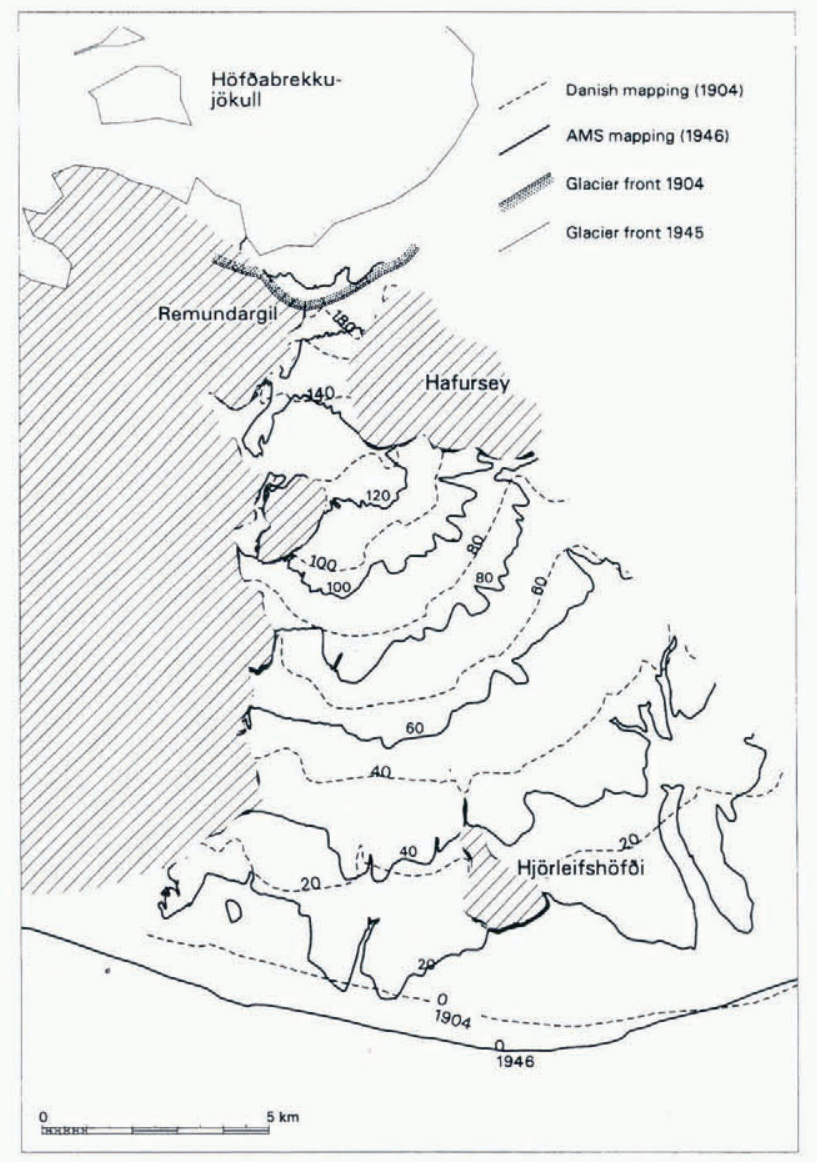

Fig. 2. Contours of the western flood path, based on maps from 1904 and 1946, which were used to calculate the volume of the flood deposits on the sandur plain. no reason to doubt this statement. The only estimate of the length of Kötlutangi at the end of the eruption is Jóhannsson's (1919). He estimated the length as $4 \mathrm{~km}$, which would indicate that the tip of Kötlutangi extended out to where the depth was over $100 \mathrm{~m}$ before the eruption. This estimate is probably an exaggeration, but both accounts (Jóhannsson, 1919; Sveinsson, 1919) agree that Kötlutangi retreated very fast in the beginning. From a sketch map (Landmælingar Íslands) based on information from Markússon in 1921 or 1922, its size was $14 \mathrm{~km}^{2}$, which indicates a volume of $0.2-0.3 \mathrm{~km}^{3}$. The initial volume may very well have been even greater.

The material deposited by the flood on Mýrdalssandur was mostly sand and fine gravel, according to Einarsson (1979) and Maizels (1993). Finer material is rarely found. The material of Kötlutangi is likely to be similar, although it might be somewhat finer. This cannot be representative of all the sediment in the flood. Some fines must be missing. Jónsson (1982) suggested that the debris flow formed gravity currents in the ocean, which flowed a long distance along the sea bottom to the south, and may have reached as far south as the Rockall deep. This is difficult to prove, but, if correct, it would have been the fines that produced the gravity currents.

The only way to estimate the amount of fines $\quad<0.02$ $\mathrm{mm}$ ) is to go by their quantity in Múlakvislas. This has been measured on a fairly regular basis over past 20 years (Pálsson and Vigfússon, 1991). The solids in Múlakvísl are partly, perhaps mostly, volcanic material from the last eruption of Katla. The fines are on average about $27 \%$ of the suspended-sediment load in Múlakvísl, which indicates that they are at least about a quarter of the amount of pumice.

The amount of tephra in the eruption was estimated at $0.7 \mathrm{~km}^{3}$ (Eggertsson, 1919; Larsen, 1993). The dry density of the airborne material was probably around $1000 \mathrm{~kg} \mathrm{~m}^{-3}$, as is that of the pumice at Mýrdalssandur. Table 1 shows the amount of suspended solids and

\section{Table 1. Quantity of eruptive and flood materials}

\begin{tabular}{lcccc}
\hline Location & Sediment & Ash & $\begin{array}{c}\text { Water/ash } \\
\text { ratio }\end{array}$ & Meltwater \\
& $\mathrm{km}^{3}$ & $\mathrm{~km}^{3}$ & & $\mathrm{~km}^{3}$ \\
\hline Mýrdalssandur & 1.00 & 0.90 & 3.5 & 3.15 \\
Kötlutangi & 0.40 & 0.35 & 3.5 & 1.25 \\
Out at sea & 0.35 & 0.30 & 3.5 & 1.05 \\
Álftaver & 0.05 & 0.05 & 3.5 & 0.15 \\
Airborne & & 0.70 & 2.5 & 1.75 \\
Pillow lava & & 0.20 & 3.5 & 0.70 \\
\hline Total & & & & \\
\hline
\end{tabular}

volcanic material in accordance with the discussion above. The dry density of all these volcanic materials is calculated as $1000 \mathrm{~kg} \mathrm{~m}^{-3}$, the same as was measured at Mýrdalssandur.

The total amount of volcanic material generated in 
the jökulhlaup was around $2.5 \mathrm{~km}^{3}$ or about $2.5 \times 10^{9} \mathrm{t}$, which corresponds to about $0.8-0.9 \mathrm{~km}^{3}$ of solid lava. The total flood water exceeded $8 \mathrm{~km}^{3}$, well over half of which was discharged in about $8 \mathrm{~h}$.

\section{EVIDENCE OF THE FLOOD NORTH OF SELFJALL AND HAFURSEY}

It is possible to estimate the maximum water level and calculate the maximum discharge of the flood from floodmarks and other evidence in the area north of Selfjall and Hafursey (Figs 3 and 4). All soil was washed off the two lowest and easternmost Lágu Hvolar hills. It is therefore clear that they were both submerged. Water did not flow through the gap between Remundargilshöfud and Lágu Hvolar, since the soil there was not affected. The Lágu Hvolar hills which were submerged are at $180 \mathrm{~m}$ a.s.l., whereas the gap lies at $184 \mathrm{~m}$ a.s.l. The water level north of the Lágu Hvolar therefore reached just over $180 \mathrm{~m}$.

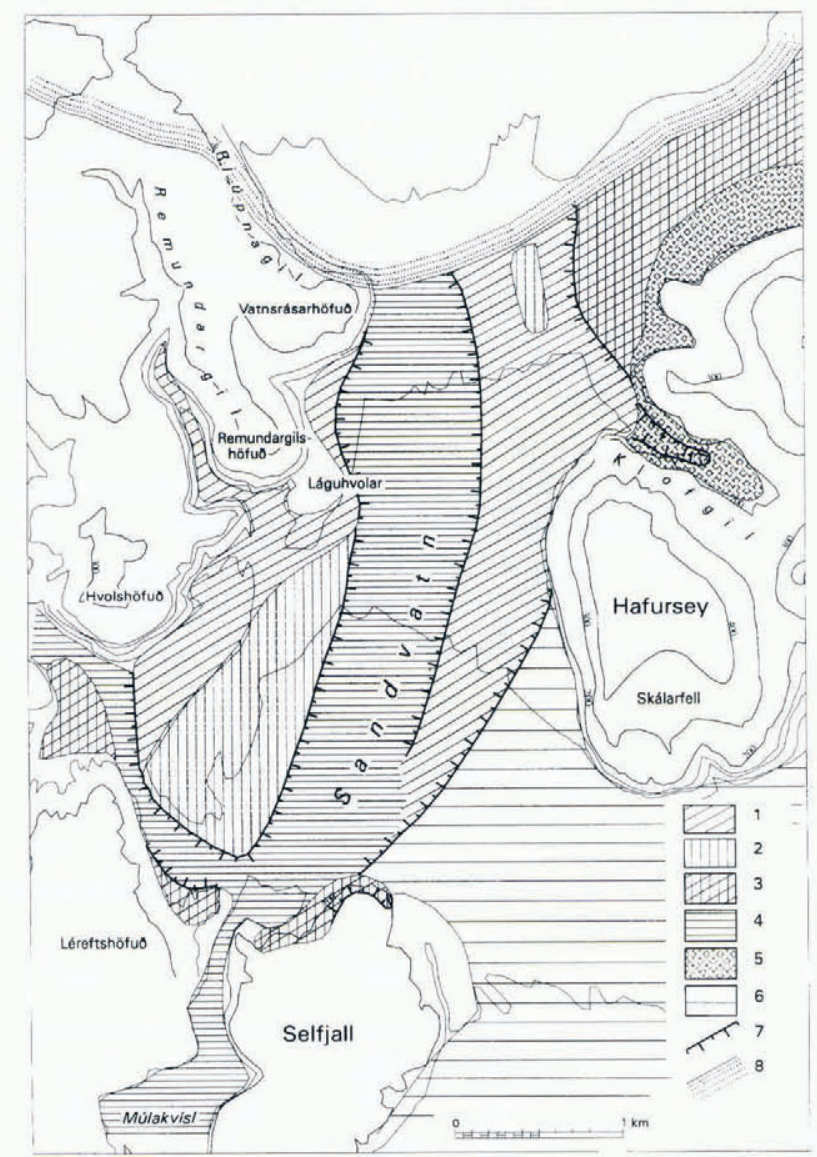

Fig. 3. Landforms north of Selfjall. 1, Alluvium with stream-bed forms; 2, hummocky moraine with kettle holes; 3, hummocky sand deposits; 4, the flow channels of Múlakvisl and Sandvatn; 5, sand dunes; 6, Mýrdalssandur; 7, prominent steep benches; 8, the glacier edge of 1918.

In 1918 the glacier reached as far as Vatnsrásarhöfud (Fig. 3), or about $1 \mathrm{~km}$ further than at present. North of Vatnsrásarhöfud the sheriff's delegates saw what they called the ravine or fissure, which they described as follows: "The flood had broken up the glacier and moved

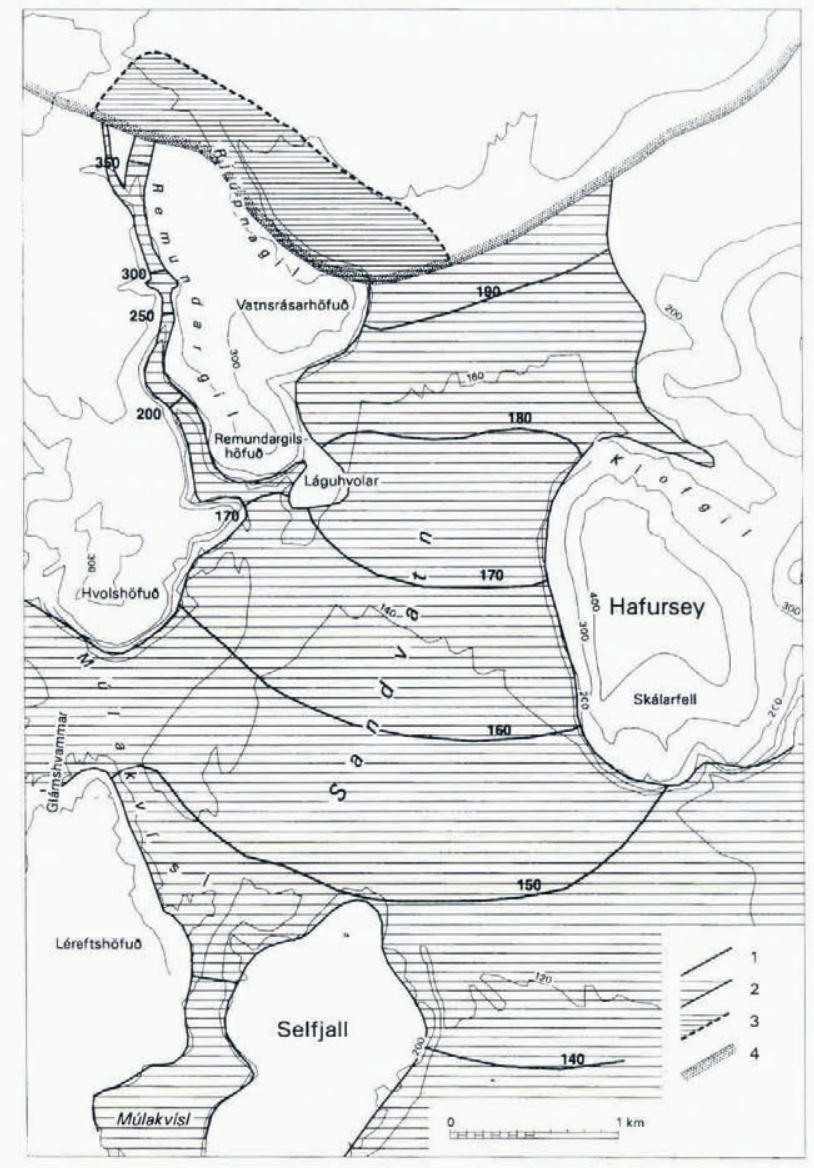

Fig. 4. The flood path and water levels north of Selfjall. 1, contours of the maximum flood level; 2, the flood path; 3, the glacier gorge, the section of the glacier that floated up during the flood; 4, the glacier edge of 1918.

it forward. The length of the gorge was 800-1000 fathoms [1460-1830 m] and the width 200-300 fathoms [366-550 $\mathrm{m}]$. It was as if a vertical cliff had been cut into the glacier where it had split apart, no less than 80 fathoms [ $145 \mathrm{~m}$ ] high". It is likely that this glacier gorge formed just before $1700 \mathrm{~h}$ on the first day of the eruption. The glacier edge at Rjúpnagil had then floated up and broken. The result was the great ice floe seen from Hjörleifshöfði and Vík, described earlier. Huge icebergs floated downstream and became stranded in the main course of Sandvatn and up by the northern side of Selfjall. The icebergs may have been $40-60 \mathrm{~m}$ high, according to photographs taken by K. Gudjónsson (Pórarinsson, 1959). The icebergs dammed Múlakvísl, and the water level north of Selfjall reached its peak during this event.

A large mass of water rushed down Remundargil (Fig. 3 ) at the beginning of the flood. Jóhannsson and his companions inspected the Remundargil gorge on the eighth day of the eruption. They estimated that the water had been up to $80 \mathrm{~m}$ deep in the gorge. Signs of the flooding may well have reached this height above the gorge floor, but water rising up the sides of the gorge probably resulted from changes in the direction of flow. Evidence of this is preserved. Just outside the mouth of the Remundargil gorge, there is a delta showing flow direction towards the gorge. This indicates that the flood from Remundargil and the flood down the glacier and Rjúpnagil met by Remundargil and that the flow past the 
Lágu Hvolar soon became much greater than the flow through Remundargil.

There is a great sand dune at the northern end of Hafursey and at Klofgil (Fig. 3). At Klogfil, benches are cut into the sand dune, and it is likely that they indicate the water level during the main flood. This place is sheltered from the main current, and wave action could easily have cut a bench into the loose eolian sand. The height of the bench, just over $180 \mathrm{~m}$, is therefore likely to mark the maximum water level of the flood, which may have been steady for some time. This level is the same as was measured at the other side of Sandvatn above Lágu Hvolar.

North of the sand dune is a hummocky surface created by an accumulation of sand and ice that forms a bench which slopes upstream from the Klofgil bench. Its surface elevation is used to reconstruct the water levels between Klofgil and the glacier edge. The same kind of deposits occur at the northern end of Selfjall. The upper limit of these sand deposits indicates that the highest water level north of Selfjall was about $150 \mathrm{~m}$, about the same as or a little higher than at Múlakvísl by Léreftshöfud.

\section{ICE TRANSPORT AND ICEBERGS}

All accounts agree that a large amount of ice was transported during the flood. Markússon described the ice in the flood as follows: "Further forwards on the sandur plain where the water spread over a larger area, many of the icebergs were stranded and resisted the current. The flood was so rough and there was so much ice, that the water itself could not be seen except where the large currents leapt forward". It seems that the discharge was greatest in these "large currents". A description from the second day of the eruption describes the signs of these large currents, but they were destroyed in later floods. The second day was therefore the only time when it was possible to inspect the dry channels of the main flood. Jóhannsson standing on Háfell wrote: "We saw clearly over the sand plain nearest to us. It was like one continuous outlet glacier all the way from Mýrdalsjökull to the sea. Large deep channels could be seen in places where the water had cut into the sand and swept away all the greater icebergs. But on both sides of these channels were high sand benches covered by gigantic icebergs".

Although the sandur plain was more or less covered in ice at the end of the first day of the eruption, a large quantity of ice was carried out to sea. There was a thick ice jam of enormous icebergs north of Selfjall and Hafursey. Any one of these ice deposits could have amounted to roughly $0.1-0.2 \mathrm{~km}^{3}$ of ice. The total estimate of ice moved amounts to some $0.5 \mathrm{~km}^{3}$, which is equivalent to about $10-15 \%$ of the total flood water.

The ice originated from three sources. First, small ice pieces and blocks were mostly formed as the flood carved into the surface of the glacier and excavated subglacial tunnels. Secondly, icebergs were formed through the upheaval of the glacier edge, from which they broke off and were carried away along about $1 \mathrm{~km}$ of the front. Very large icebergs were also formed when the flood found its way under the glacier edge and cut the great gorge that is mentioned above.
After the flood broke the glacier edge and formed the gorge in the ice, water flowed only through tunnels at the base of the glacier. The sudden halt in the flood indicates that it was dammed up when the glacier tunnel collapsed. It remained dammed until the evening of 13 October. Then the flood started again and continued for two weeks. The flow was very variable, however, which may indicate that subglacial glacier tunnels became locked every now and then. This reduced the discharge until, under increasing pressure, water found its way through again. On the whole, the discharge gradually declined during this period, with the reducing power of the eruption. The hydrograph in Figure 5 shows how the discharge may have fluctuated. The time period and amplitude of the fluctuations is inferred, but the total flow volume agrees with the previously calculated volume of the flood.

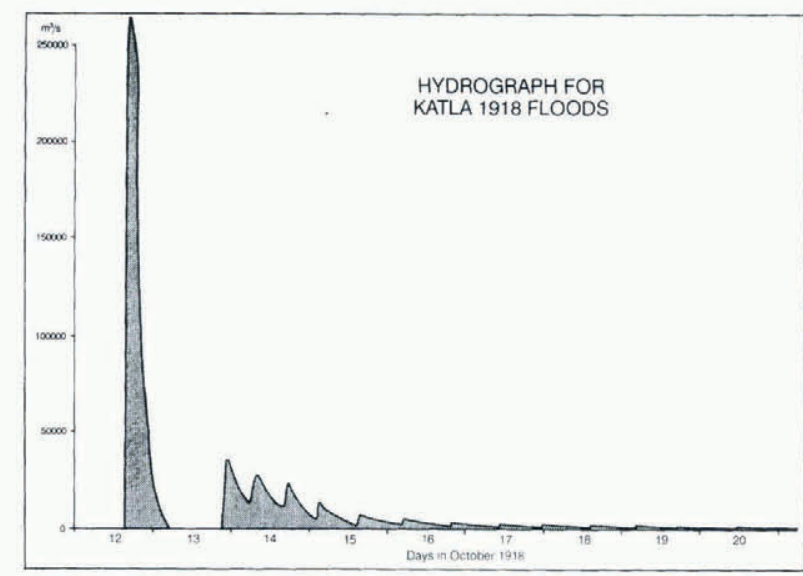

Fig. 5. Reconstructed hydrograph for the Katla 1918 floods.

Smaller bursts took place during the following weeks, the last one 4 weeks after the beginning of the eruption. The main part of the floods flowed over the sand between Hafursey and Selfjall, but the course of Múlakvísl gradually opened up and the last flood flowed that way.

\section{QUANTITATIVE ESTIMATES OF FLOW MAGNITUDE}

In order to work out the flood discharge, the flow velocity and cross-sectional area have to be known. The velocity of the flood wave was about $10 \mathrm{~ms}^{1}$ down on the sandur plain. In the deep channels, higher velocities of course occurred, with much lower velocities in the shallows where many of the icebergs became stranded. Maizels (1993) has estimated the flood velocity on the sandur plain as $10-15 \mathrm{~ms}^{-1}$ (the higher figure being for the deep channels) which is in good agreement with the above. From flood-marks, cross-sectional areas in three different locations, between Lágu Hvolar and Hafursey, between Hafursey and Selfjall and in the channel by Léreftshöfud, can be obtained.

Consistency between estimated discharges can be assessed by Manning's equation, which gives the relation between flow velocity $V$, average depth $R$, slope $i$ and flow resistance $n$ : 
Table 2. Estimated dimensions of cross-sections and calculated maximum discharges

\begin{tabular}{|c|c|c|c|c|c|c|c|}
\hline \multirow[t]{2}{*}{ Site } & $\begin{array}{c}\text { Average } \\
\text { depth }\end{array}$ & $\begin{array}{l}\text { Max. } \\
\text { depth }\end{array}$ & $\begin{array}{l}\text { Cross- } \\
\text { section }\end{array}$ & Slope & $\begin{array}{l}\text { Manning } \\
\text { coefficient }\end{array}$ & $\begin{array}{c}\text { Flow } \\
\text { velocity }\end{array}$ & Discharge \\
\hline & $\mathrm{m}$ & $\mathrm{m}$ & $\mathrm{m}^{2}$ & $S$ & $n$ & $\mathrm{~m} \mathrm{~s}^{-1}$ & $\times 10^{3} \mathrm{~m}^{3} \mathrm{~s}^{-1}$ \\
\hline Lágu Hvolar & 25 & 30 & 27.500 & 0.013 & 0.10 & 10 & 275.0 \\
\hline Selfjall & 20 & 30 & 30.000 & 0.010 & 0.09 & 9 & 270.0 \\
\hline Léreftshöfuð & 25 & 30 & 3.500 & 0.040 & 0.08 & 21 & 73.5 \\
\hline $\begin{array}{l}\text { Remundargil } \\
\text { upper }\end{array}$ & 20 & 35 & 1.600 & 0.050 & 0.08 & 28 & 44.8 \\
\hline Remundargil & & & & & & & \\
\hline lower & 20 & 25 & 3.000 & 0.050 & 0.08 & 16 & 48.0 \\
\hline
\end{tabular}

$$
V=\frac{R^{\frac{2}{3}} i^{\frac{1}{2}}}{n}
$$

Slope was taken from the contours on the map in Figure 4. The other variables are known except $n$, which can be calculated according to this equation.

The cross-section between Lágu Hvolar and Hafursey is $1100 \mathrm{~m}$ wide and the average depth was about $25 \mathrm{~m}$ based on maps and measured flood levels. Estimating flow velocity as $10 \mathrm{~m} \mathrm{~s}^{-1}$, the maximum discharge through this cross-section would have been $275 \times 10^{3} \mathrm{~m}^{3} \mathrm{~s}^{-1}$, the same as Hannesson (1934) obtained in the first effort to estimate the magnitude of the jökulhlaup. Using this discharge, the Manning coefficient, $n$, is calculated as 0.1 , about three times the value of $n$ estimated for ordinary man-made channels. This indicates enormous drag from icebergs on the ground.

The cross-section between Selfjall and Hafursey gives the same discharge if we use an average depth of $20 \mathrm{~m}$ and the flow velocity $9 \mathrm{~m} \mathrm{~s}^{-1}$. Similar calculations were made for Léreftshöfuð and Remundargil, and the results are shown in Table 2. The table also shows the variables used for the calculations. The calculations are by no means precise, but help to build an overall picture of the events. The figures for Lágu Hvolar and Selfjall refer to the maximum flood after $1700 \mathrm{~h}$, but the figures for Léreftshöfuð and Remundargil refer to the beginning of the flood, and should not therefore be added.

\section{GONCLUSIONS}

The jökulhlaup (glacier flood) from Katla, which commenced on 12 October 1918, was a gigantic event with a calculated maximum flow rate of more than $300 \times 10^{3} \mathrm{~m}^{3} \mathrm{~s}^{-1}$ of water, sediment and ice. The flood was caused by a subglacial eruption in the caldera of the Katla central volcano. About $60 \%$ of the water rushed forward in about $8 \mathrm{~h}$ during the initial stages of the eruption. Because of icebergs and ice jams, the Manning coefficient was very high in the initial flood, $n$ being about 0.1 . After a blockage of subglacial drainage channels, the flow started again on 13 October and continued for 2 weeks. The total volume of flood water that drained is estimated as $8 \mathrm{~km}^{3}$.

\section{REFERENGES}

Björnsson, H. 1993. Ýmis sjónarmid um edli Kötlugos. In Larsen, G., ed. Kötlustefna, March 27-29, ágrip erinda (abstracts). Reykjavík, Raunvísindastofnun, 11-13. (Háskólans Fjölrit RH-3-93.

Eggertsson, S. 1919. Ýmislegt smávegis viðvíkandi Kötlugosinu 1918. Eimreidin, 25(4), $212-222$.

Einarsson, G. 1979. Mýrdalssandur pumice deposit. Reykjavík, Iðntœkinistofnun. (79-05.

Hannesson, P. 1934. Kötlugosið siðasta. Nättürufredingurinn, 4(1), 1-4.

Jóhannsson, G. 1919. Köllugosid 1918. Reykjavík, Bókaverzlun Ársœls Árnasonar.

Jónsson, J. 1980. Um Kötluhlaup. Náltúrufraddingurinn, 50(2), 81-86.

Jónsson, J. 1982. Notes on the Katla volcanoglacial debris flows. Jökull, 32, 61-68.

Karlsson, T. 1984. Kötluhlaup 1918 - vangaveltur um edli hlaupsins og hámarksrennsli. In Guðmundsson, G. T., ed. Fardfrèdafélag IslandsKötlustefna, February 26. Reykjavík, Dagskrá og ágrip erinda 10-12. [Abstracts.]

Larsen, G. 1993. Nokkur ord um Kötlugjósku. In Larsen, G., ed. Kötlustefna, March 27-29, ágrip erinda (abstracts). Reykjavík, Raunvísindastofnun, 6-7. (Háskólans Fjölrit RH-3-93.

Maizels, J.K. 1991. The origin and evolution of Holocene sandur deposits in areas of jökulhlaup drainage, Iceland. In Maizels, J. K. and C. Caseldine, eds. Environmental change in Iceland: past and present. Dordrecht, etc., Kluwer Academic Publishers, 267-302. (Glaciology and Quaternary Geology 7.)

Maizels, J. K. 1992. Boulder ring structures produced during jökulhlaup flows - origin and hydraulic significance. Geogr. Ann., 74A(1), 21-33.

Maizels, J. K. 1993. Lithofacies variations within sandur deposits: the role of runoff regime, flow dynamics and sediment supply characteristics. Sediment. Geol., 85, 299-325.

Pálsson, S. and G.H. Vigfússon. 1991. Niðurstödur svifsursmelinga 19631990. Reykjavík, Orkustofnun. (Report OS-91017/VOD-03B.

Sveinsson, G. 1919. Köllugosid 1918 og afleidingar pess. Reykjavík, Prentsmidjan Gutenberg.

Pórarinsson, S. 1959. Um möguleika á pví ad ósegja fyrir um næsta Kötlugos. Jökull, 9, 6-18. 